\title{
The User, Capability and Technology in the Microfinance Industry
}

\author{
Mustafa Kagalwala
}

Symbiosis School for Liberal Arts

\begin{abstract}
Studies have long focused on poverty alleviation in different ways. Development Economics has tried to formulate and suggest a number of theories which try to tackle the problem of poverty and development. One of the most discussed themes of this century in this field is Microfinance.

Microfinance or Microcredit is about banking the un-bankable, bringing credit, savings and other essential financial services with the reach of tens - or rather hundreds - of millions of people who are too poor to be served by regular banks, in most cases because they are unable to offer sufficient collateral (Gert van Maanen, Microcredit: Sound Business or Development Instrument, 2004.)

Microfinance is now being discussed worldwide for it has been one of the only few development and poverty alleviation instruments which has shown fast and visible results in decreasing poverty and increasing development. Microfinance helps the lower classes to stay away from the confines of local loan sharks. Microcredit as a formal lending structure was started in Bangladesh under the banner of The Grameen Bank by Mohammed Yunus. His model of lending was replicated worldwide. Microfinance has been replicated in more than twenty countries in Africa, five countries in Europe and in more than thirty countries in Asia and the Americas.
\end{abstract}

The number of microfinance Institutions worldwide have increased since then and are still on the rise. Micro Finance Institutions have started digging deeper and are constantly trying to overcome hurdles in the reach and success of financial inclusion. Technological changes have been the focus of both Microfinance Institutions and the government to further the goals of financial inclusion in India.

This paper will list down the efforts taken by the RBI, the government and MFI's in the field of technological and organisational advancement. It will dwell upon and highlight the importance of digitization and technological advancement in the microfinance sector. This paper will use Amartya Sen's capability approach as an important philosophical reflection which could be used in introducing technology whilst keeping in mind the end result and end user.

\section{Keywords and Definitions}

\section{Financial Inclusion}

Financial inclusion broadens the resource base of the financial system by developing a culture of savings among large segment of rural population and plays its own role in the process of economic development. Further, by bringing low income groups within the perimeter of formal banking sector; financial inclusion protects their financial wealth and other resources in exigent circumstances. Financial inclusion also mitigates the exploitation of vulnerable sections by the usurious money lenders by facilitating easy access to formal credit. $^{l}$

Financial inclusion may be defined as the process of ensuring access to financial services and timely and adequate credit where needed by vulnerable groups such as weaker sections and low income groups at an affordable cost. ${ }^{2}$

Financial Inclusion, broadly defined, refers to universal access to a wide range of financial services at a reasonable cost. These include not only banking products but also other financial services such as insurance and equity products. ${ }^{3}$

\footnotetext{
${ }^{1}$ Financial Inclusion in India - An Assessment, Reserve Bank of India.

${ }^{2}$ The committee on Financial Inclusion, Chairman: Dr. C. Rangarajan

${ }^{3}$ The committee on Financial Sector reforms, Chairman: Dr. R. G. Rajan 


\section{Microfinance Institution (MFI)}

A microfinance institution is an organization that offers financial services to low income populations. Almost all give loans to their members, and many offer insurance, deposit and other services. A great scale of organizations is regarded as microfinance institutes. ${ }^{4}$

\section{NBFC-MFI}

A Non Banking Finance Company-Microfinance Institution is defined as a non-deposit taking Non Banking Finance Company (other than a company licensed under Section 25 of the Indian Companies Act, 1956) that fulfils the following conditions:

i. Minimum Net Owned Funds of Rs.5 crore. (For NBFC-MFIs registered in the North Eastern Region of the country, the minimum NOF requirement shall stand at Rs. 2 crore).

ii. Not less than $85 \%$ of its net assets are in the nature of "qualifying assets. "5

\section{OUTREACH OF MiCROFinanCE InSTITUTIONS}

MFI's operate in 29 states, 4 Union Territories and 588 districts. The following is the presence of the top Microfinance Institutions (in number of states).

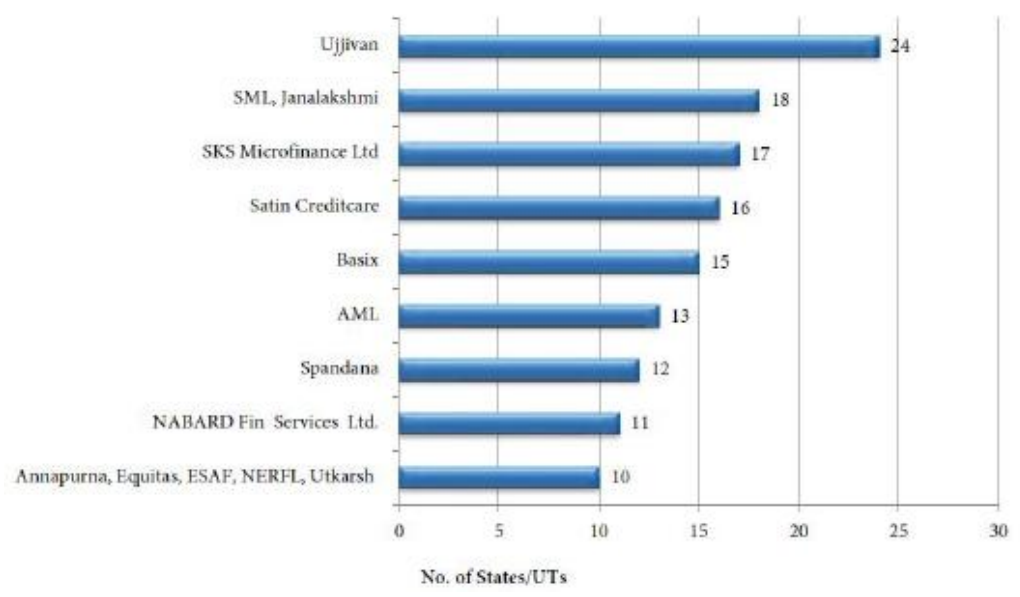

This figure has been extracted from The Bharat Microfinance Report, 2016

The total number of Microfinance institute branches in India is 11,644, out of which NBFC-MFI's account for 9775 branches. SKS Microfinance Institute accounts for 1191 branches of these 9775 branches in India. ${ }^{6}$

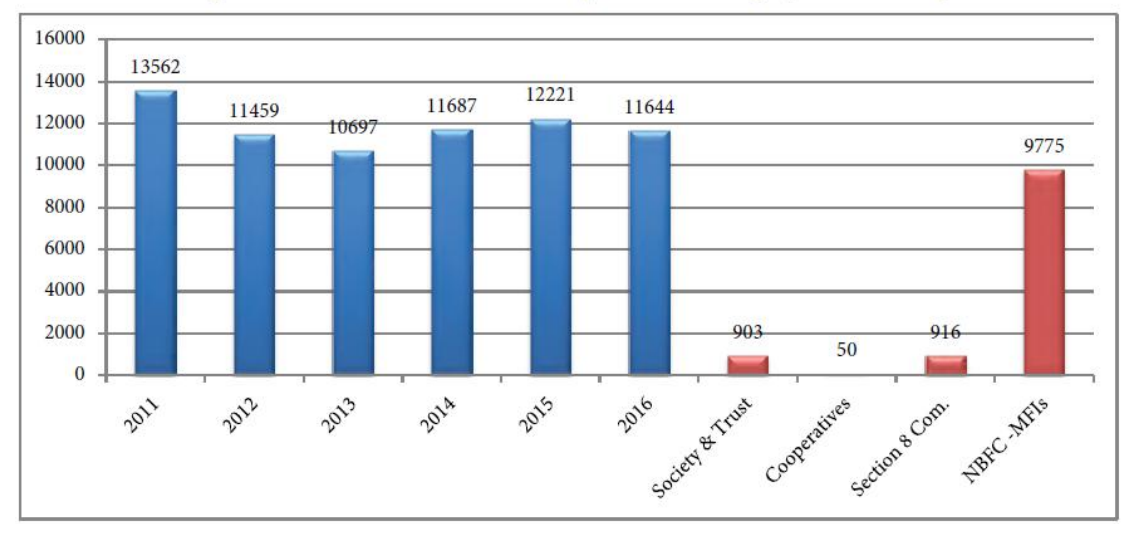

This figure has been extracted from The Bharat Microfinance Institution, 2016.

The total number customers served by Microfinance Institutes were 399 Lakh in 2016, out of which 339 Lakh clients were of NBFC-MFI's. ${ }^{7}$

\footnotetext{
${ }^{4}$ www.microfinanceinfo.com/micro-financial-institutions/

${ }^{5}$ Introduction of New Category of NBFCs - 'Non Banking Financial Company-Micro Finance Institutions' (NBFCMFIs), Reserve Bank of India.

${ }^{6}$ The Bharat Microfinance Report, 2016.
} 


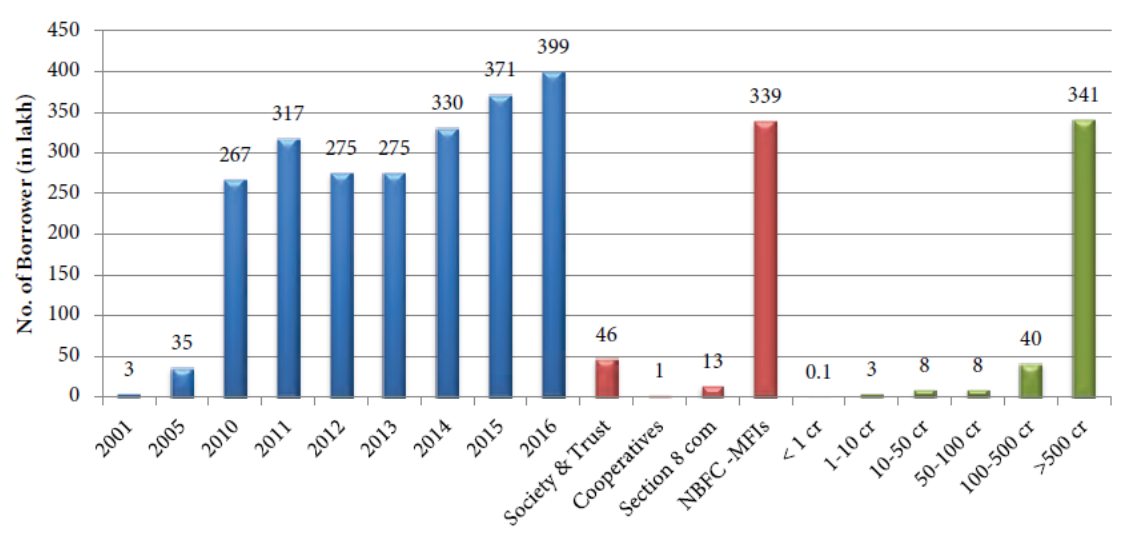

This figure has been extracted from The Bharat Microfinance Report, 2016.

The Urban-Rural Breakup of gross loan by Microfinance institutions is $72 \%$ Rural and $28 \%$ Urban for 2016.

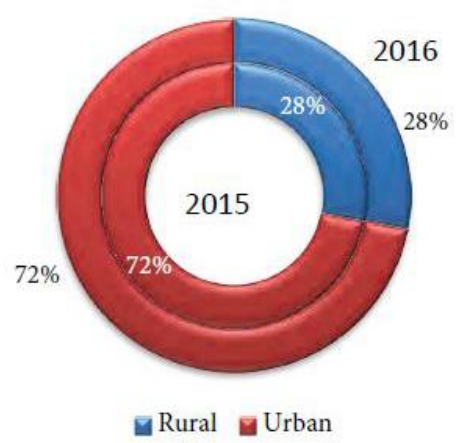

This figure has been extracted from The Bharat Microfinance Report, 2016.

This shows the need for growth in the rural sector. The reach in the Urban sector is more because of many reasons, some of them are:

1) Ease of access differences. An Urban poverty struck area was relatively easy to access compared to a rural poverty struck area.

2) Difference of information and awareness between the urban and poor people. Urban population is much more aware of technology and opportunities which could enable their growth compared to rural areas.

3) Technological user friendliness is much more in urban areas than that of rural areas.

\section{HURDLES FOR MiCROFINANCE INSTITUTIONS}

After 2012, Microfinance institutions have been constantly growing in terms of loan portfolio. Only 2016 showed a downfall in growth rate of loan portfolio from $33 \%$ to $31 \%$ because of Bandhan Bank's exit from the microfinance sector. However, the client outreach of these Microfinance Institutions has been decreasing since 2014 from $20 \%$ to $8 \%$ in $2016^{8}$. In spite of the effective and successful growth of Microfinance institutes there is much which remains to be done. According to a World Bank report, less than 35\% of Indians have a bank account or access to formal financial institutions. In spite of the strong performance of microfinance institutions in rural and urban areas, a few hurdles stop the outreach of clients and loans.

Every Organization including microfinance organizations have an environment they function in. This environment affects its functioning, growth, progress and possibility of achieving set goals. Within this environment which exists there are two types of environments. The first type is internal and the second is external. The internal environment is the company and its elements, the elements would involve processes, resources, assets etc. The external environment has two parts: 1) Micro

\footnotetext{
${ }^{7}$ The Bharat Microfinance Report, 2016.

${ }^{8}$ The Bharat Microfinance Report, Sa-Dhan, 2016.
} 
environment 2) Macro environment. The Micro environment would include customers, suppliers and competitors. The Macro environment would involve: 1) Political, Economic, Social and Technological factors which affect the organisation. ${ }^{9}$ There are many hurdles to growth of microfinance institutions; however this paper will only address ones which are in connection to the topic of this paper.

The following are the internal environment (operational) problems the organisation faces ${ }^{10}$ :

1) Adaptation to Financial Technology: Many medium and small Microfinance institutions do not have the money and funds to adapt to technology which could help further their goals. Even large Microfinance industries have not been able to use technology to the fullest. For example, only SKS microfinance uses biometric scanners for majority of transactions. Other institutions have not taken up this technology completely. Also, electricity and power being a serious concern in various rural areas stops the Microfinance institutions from reaching out to a larger through technology.

2) Usage of Cash: Rural and urban, both these segments of the Indian economy use cash as the primary mode of transaction. Cash handling is a difficult task which also decreases association with technology. Cash handling also affects operational efficiency. Counting cash takes time away from microfinance institutions. A few hours of the MFI goes only in counting cash. Centre meetings are restricted to and revolve around bank timings as deposition of cash is an important factor. Along with operational inefficiency the staff's safety also comes into the picture, the staff handles a lot of cash and cash management leads to leakages very often.

3) Lack of Quality Staff Members: Due to low interest rates i.e. low income and high costs attached to the nature of the business microfinance firms find it difficult to recruit efficient, qualified and highly productive individuals for their firms. The lack of high quality human resource also effects the operations of microfinance.

4) Lack of Funds and Capital to Expand and Lend: In order to extend its loan portfolio and increase its reach in urban and rural area microfinance institutions will need capital through funds etc. Funds are dependent on the financial firm's credit rating. Again, if the credit rating is not high (which may also be the reflection of manual processes and less automation) the microfinance institution is unable to achieve growth.

\section{THE WAY FORWARD}

This paper proposes a two way framework for the growth of the Microfinance Institutions in the field of financial inclusion. The first is through the use of financial technology and digitization, the subject of technology is a concept which has been taken into consideration by various institutions and especially the current Indian government. Along with growth in financial technology, this paper proposes its second argument, perhaps a subject not given much importance, the subject of financial, technological and digital literacy and its importance. This paper will connect Amartya Sen's capability approach to financial inclusion and provide a theoretical framework for the growth of financial, technological and digital literacy in the field of microfinance.

\section{IMPORTANCE OF FinANCIAL TECHNOLOGY}

\section{Technology as a Means to Overcome Hurdles:}

The microfinance industry has started accepting various solutions to the problems mentioned in section IV of this paper. One of the biggest solutions the microfinance industry can take up is different types and forms of digitization in every level of its working. The government and the private sector both are trying to help financial inclusion by promoting both cashless and digital financial services.

The government has introduced many new projects under digitization. Some of them are the Aadhar Enabled Payment System and the United Payment Interface. The Modi government demonetized 500 and 1000 Rupee bills. The government justified its move by saying that it had done this primarily to bring out black money and stop terrorism. As time progressed the government's justification for this

\footnotetext{
${ }^{9}$ The impact of micro macro environment, Oxford School of Marketing.

${ }^{10}$ Shifting Trends in the Microfinance Ecosystem, Pwc, 2016.
} 
move started weakening and thereby it had to change goal posts. The government then brought about the concept of making India cash-less. This suited the government very well. The government thus started trying to solve the cash issue in India. The government then took various steps like development of the Aadhar Enabled Payment System (AEPS )and the United Payment Interface (UPI). The government started the National Uniform USSD Platform (NUUP) ${ }^{11}$ through which one can make money transfers without the internet. The government converted Kisan Cards to RuPay cards. The government is also incentivizing its citizens for making digital payments by offering $0.75 \%$ discount on government owned petrol pumps. The government is also extending 2 Point of Sales (POS) devices to 1 Lakh villages through eligible financial institutions. It is also providing 4.32 crore Rupay Kisan Credit cards to further digital transactions. Many such initiatives have been taken up by the government to push for financial inclusion. All these actions will compliment the growth of Microfinance institutions; this is good news for financial inclusion. These incentives and digital development will prove to be very important for financial inclusion.

The private sector is also providing technologies through which digitisation can be achieved. IndiaQR which replaces the need of PoS machines, electronic wallets like Freecharge and PayTm, mobile banking have increased the type and number of payment options.

Microfinance institutions in order to keep up their loan portfolio, growth outreach and keep stable and low interest rates have to look out for opportunities in technology and digitization. They have to develop an attitude for acceptance for such technology. The government is the best ally for MFI's. The government has involved private enterprises in realising financial inclusion in India through many schemes like Business Correspondance, Payment Banks etc. Thus, technology and innovation in technology will witness exponential growth and will always be there to aid MFI's. Technological expansions will decrease internal costs as less manpower will be used since technology will substitute much of the internal human capital. Further, the growth of outreach will help provide economies of scale hence allowing microfinance institutions keep low interests and extend a larger number of loans to people in both urban and rural areas. ${ }^{12}$

\section{IMPORTANCE OF FinANCIAL, TECHNOLOGICAL LiTERACY}

\section{Amartya Sen's Capability Approach Extended to Microfinance Institutions}

Noble Laureate Amartya Sen has developed one of the most important theories in welfare economics. Microfinance would definitely come under the ambit of welfare economics or development economics and his philosophy and inference must also be viewed in context to microfinance. Let us briefly talk about the capability approach.

Amartya Sen argues that economic growth and prosperity has conventionally been viewed as the end objective in today's world. However, it is not so. The ultimate end of economic growth must be seen as enriching peoples' lives. It must be the end objective. Amertya Sen argues,

"First, economic prosperity is no more than one of the means to enriching lives of people. It is a foundational conclusion to give it the status of an end. Secondly, even as a means, merely enhancing average economic opulence can be quite inefficient in the pursuit of the really valuable ends",13

Thus, capability must be seen as 'doings and beings' which could be called 'functioning'. What is of primary importance is the capability to function.

Amartya Sen argues "If life is seen as a set of "doings and beings" that are valuable, the exercise of assessing the quality of life takes the form of 44 evaluating these 'functionings' and the capability to function. This valuational exercise cannot be done by focusing simply on commodities or incomes that help those doings and beings, as in commodity-based accounting of the quality of life (involving a confusion of means and ends). "The life of money-making", as Aristotle put it, "is one undertaken under compulsion, and wealth is evidently not the good we are seeking; for it is merely useful and for the sake of something else." The task is that of evaluating the importance of the various functionings in human life, going beyond what Marx called, in a different but related context, "commodity fetishism". The functionings themselves have to be examined, and the capability of the person to achieve them has to be appropriately valued." 14

\footnotetext{
${ }^{11}$ NUUP FAQ's, NPCI, 2017.

${ }^{12}$ Role of Technology in Microfinance Sector in India, M. Sravani, 2013.

${ }^{13}$ Introduction, Development as Capability Expansion, Amartya Sen, 2003.

${ }^{14}$ Commodities, functioning and capabilities, Development as Capability Expansion, Amartya Sen, 2003.
} 
Money is a resource which is not the objective, the capability to use this money is more important. On the side of microfinance one could say that high repayment rates are an indicator of this capability to function with money. Thereby to microfinance this question of capability to use the money could be less important. However, what is very important is whether the poor have the capability to use the technologies the government and microfinance institutions are trying to acquire, develop and use? The answer to this question is no. Let us take an example of the capability approach, if we as the government provide a cycle to the village the question should not only be why give the cycle but should be if the villagers know how to ride a cycle, do they have the ability to service their cycles regularly? Are they 'capable' enough to use the cycle?

Thus, extending the capability approach to microfinance, financial and digital technologies would be relatively of lesser importance than that of the capability of rural and urban households to use these technologies. In India, statistics of financial literacy show that a majority of the population is financially illiterate. Further, a majority of the population is not aware of the already existing financial technology; leave alone the capability to use it. ${ }^{15}$ Thus, microfinance institutions in order to implement technology to further the goals of financial inclusion have to address the problem of financial, technological and digital literacy. If technology is imagined to be the catalyst for outreach of financial inclusion then financial literacy is the most important element of this reaction. The use of financial technology in the existence of financial, technological and digital literacy would prove to be unfruitful.

\section{Case Study from Africa ${ }^{16}$}

Let us now look at a case study as to how financial technology from the private sector helps in removing intermediaries leads to increase in funds extended by the Microfinance institution. If a Microfinance gets funding from an external private source the borrower ends up paying 35\% interest on the loan due to intermediate expenses. Kiva, a website helps the borrower get the same loan at a zero interest rate charge. The total transaction cost directly via internet would come up to be only 5\% per annum. Many microfinance institutions and even private borrowers take help from this website. The lender only has to select whom he/she wants to give the loan to. Microfinance institutions normally rate its clientele, based on the clients credit history, this rating is used by the lender to choose his/her borrower. Technology has thus made the availability of funds a very easy task now.

The aforementioned examples and technologies thus show that costs in the functioning of MFI's can come down drastically. A study shows that costs for managing physical accounts go down by $80 \%$ $90 \%$ when we shift to managing digital accounts. ${ }^{17}$ If microfinance institutions transforms themselves by including digitization and technological developments the goals of financial inclusion will soon be realised. The aforementioned 'hurdles' of microfinance institutes will be negated. With low costs, institutions can recruit well trained, professional employees who would help microfinance institutions realize its goals.

In the Indian context the above technology can be used in two ways. The first way to use this technology would be through an institution i.e. microfinance institution. The second way would be in which the borrower directly puts his application for a loan online. Both these ways would require knowledge and access to technology which is a challenge for the machinery which compliments financial inclusion i.e. the government and other private institutions. These challenges need to be addressed as soon as possible for capability of usage of technology will boost the microfinance sector.

\section{RECOMMENDED STEPS}

\section{1) Integration of Education as One of the Core Activities}

Mohammed Yunus, in his book Banker to the poor mentions about his workshops for the people borrowing from the bank. Through the 16 decisions he transformed their ideas about growth. There were tests which were carried out by the microfinance institutions for the borrowers before they could lend money. This system ensured the borrowers had the potential to pay back their loans. ${ }^{18}$ If

\footnotetext{
${ }^{15}$ A Digital Pathway to Financial Inclusion, Dan Radcliffe and Rodger Voorhies, 2012.

${ }^{16} \mathrm{http}: / /$ www.ibtimes.co.uk/how-fintech-microfinance-remove-intermediaries-loan-costs-1572760

${ }^{17}$ Digital Finance For All: Powering Inclusive Growth In Emerging Economies, September 2016.

${ }^{18}$ Banker to the poor, Mohammed Yunus
} 
microfinance institutes do invest time in interaction with their borrowers in different ways, financial education in terms of use of financial technology must be one of the most important agendas of microfinance institutions. This must be looked as an investment, as it will complement the desired effect of the technology. Technology will in turn help the growth of outreach and economies of scales will lead to greater profits.

\section{2) HRM Practices}

Microfinance Institutions also have a problem in their internal environment. The employees themselves are unaware of the processes and intricacies involved in financial technology. ${ }^{19}$ Thus, it is important that the employees also have to be trained in financial technology. Also necessary training to train borrowers both urban and rural needs to be provided a set of employees who will train the borrowers.

\section{CONCLUSION}

This article first tracks down the performance of microfinance institutions in India. It then looks at the problems microfinance institutes face today and the solutions which we envision to tackle them. This paper then proposes a two way framework for furthering the goals of financial inclusion and growth of microfinance institutions. The first way to achieve these objectives is use of financial technology to increase the growth and impact of MFI's, since the most important solution which has emerged is greater use of financial technology which will reduce costs and increase profits for microfinance along with realising the goals of financial inclusion. This paper dwells on the capability of the end user to use the technology which we are looking forward to use in the future and in the contemporary world.

The second way to achieve this goal is financial, technological and digital literacy. This paper connects the capability approach to microfinance and provides a theoretical framework for growth of financial, technological and digital literacy in microfinance. The paper does not intend to negate the heavy importance given to development of technology it only proposes a simultaneous growth or rather preparation for usage of the technology which policy makers envision as solutions to contemporary problems in microfinance.

\section{REFERENCES}

[1] The Bharat Microfinance Report, Sa-Dhan, 2016.

[2] Digital Microfinance For All: Powering Inclusive Growth In Emerging Economies, James Manyika, Susan Lund, Marc Singer, Olivia White, and Chris Berry, 2016.

[3] Digital Financial Services and Microfinance: State Of Play, Sonia Arenaza, 2014.

[4] Microfinance and Mobile Banking: The Story So Far, Kabir Kumar, Clauda Mckay, Sarah Rotman, 2010.

[5] A Digital Pathway to Financial Inclusion, Dan Radcliffe and Rodger Voorhies, 2012.

[6] Shifting Trends in the Microfinance Ecosystem, Pwc, 2016.

[7] Microfinance in India: Digital Financial Inclusion, Malarvizhi \& Munja, 2016.

[8] Role of Technology in Microfinance Sector in India, M. Sravani, 2013.

[9] Development as Capability Expansion, Amartya Sen, 2003.

[10] Banker to the Poor, Mohammed Yunus, 1999.

${ }^{19}$ The Bharat Microfinance Report, Sa-Dhan, 2016. 